\title{
İçme Suyu Kaynaklarında Hidrodinamik Kavitasyon Yöntemi İle Mikrobiyal Kirlilik Giderimi
}

\author{
Efsun DINDAR \\ Uludağ Üniversitesi, Mühendislik Fakültesi, Çevre Mühendisliği Bölümü, Bursa
}

Sorumlu yazar e-mail (Corresponding author e-mail): efsun@uludag.edu.tr

Geliș tarihi (Received) : 27.12.2018

Kabul tarihi (Accepted): 05.03.2019

DOI : $10.21657 /$ topraksu.544670

\section{Öz}

Bu çalıșmada, içme suyu olarak kullanılan ham su, orifis bazlı bir hidrodinamik kavitasyon cihazı ile laboratuvar ölçeğinde mekanik olarak kavite edilmiștir. Hidrodinamik kavitasyon seti 25 L'ik bir tank ve 1,5 kW'Iık pozitif yer değiștirme pompasında olușan bir cihazdır. Cihazda $3 \mathrm{~mm}$ çapında tek delikli orifis plaka kullanıımıștır. Sistemin ana hattının çapı 19 mm olup hava girișini önlemek için deșarj borusu tanktaki sıvı seviyesinin altına yerleștirilmiștir. Hidrodinamik kavitasyon çalıșması 150 dk yürütülmüș olup 0, 30, 60, 90, 120, ve 150. dk'larda tanktan numune alınmıștır. Optimum kavitasyon zamanı 5 bar basınçta 60-90 dk arasında bulunmuștur. Sonuçlar incelendiğinde, $90 \mathrm{dk}$ sonunda \%94-\%100 (1,23 log) arasında bakteriyel giderimin gerçekleștiği görülmüștür. Çalıșma verileri, hidrodinamik kavitasyonun hücre parçalayarak bakteri aktifliğini azaltmada etkili olduğunu ortaya koymuștur. İçilebilir nitelikteki suların mikrobiyal dezenfeksiyonu için hidrodinamik kavitasyon etkili bir șekilde kullanılabilir bir sistemdir.

Anahtar Kelimeler: Bakteri, dezenfeksiyon, hidrodinamik kavitasyon, içme suyu, toplam bakteri sayısı.

\section{Microbial Removal of Drinking Water Resources by Hydrodynamic Cavitation Method}

\begin{abstract}
The effect of hydrodynamic cavitation $(\mathrm{HC})$ on the removal of microorganisms in potable water were investigated using a laboratory scale device. The hydrodynamic cavitation setup consisted of a $25 \mathrm{~L}$ tank, a positive displacement pump $(1.5 \mathrm{~kW})$, and a cavitation device. Single-hole orifice plates with diameters of $3 \mathrm{~mm}$ was used as cavitation devices. The diameter of the main line was $19 \mathrm{~mm}$, and the discharge well was placed below the liquid level in the tank to avoid introducing air. Hydrodynamic cavitation experiments were run for $150 \mathrm{~min}$, and the samples were collected from the tank at 0,30 , $60,90,120$, and $150 \mathrm{~min}$. The optimal cavitation time was 60-90 min with a pump pressure of 5 bar. Results showed that after 90 min of cavitation, bacterial removal percentages of $94 \%$ to $100 \%(\log 1.23)$ were obtained. Experiments showed that hydrodynamic cavitationis very effective in reducing bacterial ability. Hydrodynamic cavitation can be effectively used for the microbial disinfection of potable water.
\end{abstract}

Key word: Bacteria, disinfection, hydrodynamic cavitation, potable water, total bacteria count

\section{GíRiș}

İçme suyu kalitesi günümüzde oldukça önemli bir konudur. Son yıllarda endüstriyel kirlilikler, tarımsal faaliyetler ve nüfus artıșına bağlı

olarak çoğalan evsel atıklardan dolayı içilebilir nitelikteki suların kalitesi düșmektedir. Bu durum patojen mikroorganizmaların çoğalmasına 
neden olarak sudan bulașan ölümcül olabilen hastalıkların ortaya çıkmasına sebep olmaktadır. Kirliliğin kontrol edilmesi veya etkili arıtma yöntemlerinin kullanılmasıyla içme suyu kalitesi iyileștirilebilmektedir.

Kimyasal, fiziksel ve biyolojik kirliliklerin giderilmesi için çeșitli arıtma yöntemleri kullanılmaktadır. Hastalık yapıcı mikroorganizmaların sebep olduğu biyolojik kirliliği gidermek için dezenfeksiyon ișlemi yapılmaktadır. Dezenfeksiyonun amacı insan sağlığı açısından riskli olan mikroorganizmaları ortadan kaldırmaktır. Uzun yıllardır suların dezenfeksiyonun da çeșitli kimyasal ve fiziksel yöntemler uygulanmaktadır. Klorlama, ozonlama ve ultraviyole ıșığı gibi içilebilir su dezenfeksiyonu için rutin olarak çeșitli fiziksel ve kimyasal teknikler kullanılmaktadır (Haas vd., 1990; Labatiuk vd., 1992; Giese ve Darby, 2000). Ancak kimyasal dezenfeksiyon teknikleri, kanserojen yan ürünlerin olușumu gibi dezavantajlara sahip olabilmektedir. Bu nedenle, bazı yöntemlerin dezavantajları, etkinliklerinden daha fazla olduğu için alternatif bașka tekniklerin geliștirilmesine intiyaç duyulmaktadır.

Su arıtımında yeni yöntemlerin araștırılması için hala birçok faaliyet alanı bulunmaktadır. Kavitasyon prosesi de bu alanlardan biri olarak görülmektedir. Kavitasyon, bir sıvı içinde mikro kabarcıkların olușumu, büyümesi ve çökmesi olarak bilinmektedir (Jyoti ve Pandit, 2001). Sivı, zaman içinde ve mesafe boyunca basınç alanında değișimlere maruz kaldığında, baloncukların olușmasına neden olur. Bu baloncuklar hem sıvıdan gelen buharla hem de sıvıdaki çözünmüș gazlarla dolar ve sonra șiddetli sıkıșma ile içeriye doğru patlar. Hidrodinamik kavitasyon, bir orifis, vana ya da ventüri gibi dar bir geçitten sıvının geçmesi ile olușturulmaktadır.

Arrojo vd., (2008) yaptıkları çalıșmada, E. coli konsantrasyonu arttıkça orifis plakasında hız sabiti orta derecede azaldığını, ventüri tipi uygulamada ise aynı kaldığını bulmușlardır. Orifis plakalarda, dezenfeksiyonun bir kısmı OH radikali üretimi ile ilișkilidir ve bu nedenle, E. coli konsantrasyonu arttıkça, radikal konsantrasyonu sınırlayıcı etki göstermektedir. Diğer yandan ventüri tipi tasarımın etkilenmesinin sebebi, reaktantın sınırlayıcı olmaması dolayısıyla bakterilerin mekanik bozulmasının süreçte önemli bir rol oynaması olarak açıklanmaktadır.
Jyoti ve Pandit (2001) yaptıkları çalıșma sonucunda hidrodinamik kavitasyonun içme suyu üretimi için potansiyel bir fiziki su dezenfeksiyon tekniği olduğunu bulmușlardır. Save vd. (1994) özellikle hücre bozulmasında hidrodinamik kavitasyonun etkili olduğunu ortaya koymușlardır. Balasundaram ve Harrison (2006) yaptıkları çalıșmada orifis plaka kullanarak E.colínin parçalanmasını sağlayarak hücre içi proteinlerin organizmadan serbest bırakıldığını bulmușlardır.

Hidrodinamik kavitasyon ile E.coli için yüksek deaktivasyon elde edildiği yapılan çalıșmalarla belirlenmiștir (Arrojo vd., 2008; Mezule vd., 2009). Li vd. (2016) hidrodinamik kavitasyon prosesinin ürettiği serbest radikaller ile membran lipitleri dahil olmak üzere hücresel bileșenlerin zarar gördüğünü tespit etmișlerdir. Hidrodinamik kavitasyonun dezenfeksiyon etkisi, aynı anda hareket eden mekanizmaların kombinasyonu olarak açıklanmaktadır (Mason vd., 2003).

-Mekanik etkiler: Türbülans üretimi, SIVı sirkülasyon akımları ve makaslama gerilmeleri.

-Kimyasal etkiler: Aktif serbest radikallerin olușması.

-Isı etkileri: Lokal sıcak noktaların üretimi (çok yüksek sıcaklık ve basıncın lokal olarak durumu).

Bu bağlamda çalıșmanın amacı, içme suyu amaçlı su dezenfeksiyonunda alternatif bir metot olarak hidrodinamik kavitasyon sisteminin, mikrobiyal giderim üzerine etkisini ortaya koymaktır. Çalıșma kapsamında, kimyasal madde ilavesi olmadan su dezenfeksiyonunda hidrodinamik kavitasyonun kullanılabilirliğini araștırılmıștır. İçme suyunda kirlilik göstergesi olarak görülen spesifik mikroorganizmalar (Clostridium perfiringens, Enterekok, Escherichia Coli, Pseudomonas aeruginosa, Toplam Bakteri Sayısı, Toplam Koliform) seçilerek çalıșma yapılmıștır.

\section{MATERYAL VE YÖNTEM}

\section{Materyal}

Bu çalıșmada kullanılan su, Bursa'da bulunan, Bursa Büyükșehir Belediyesi, BUSKi Genel Müdürlüğü bünyesindeki Dobruca İçme Suyu Arıtma Tesisi girișinden alınmıștır. Su, Doğancı Barajından $\varnothing 1600 \mathrm{~mm}$ çapında, (3300 mt.) uzunluğunda çelik boru ile alınarak, tesise gelmektedir. Çalıșma kapsamında kullanılan su özellikleri Tablo 1'de verilmiștir. 
Çizelge 1. Calıșmada kullanılan içilebilir suyun özellikleri Table 1. Microbial characterization of potable water used in the study

\begin{tabular}{lc}
\hline Parametre & Değer \\
\hline Clostridium perfiringens (MF) CFU/100 ml & 1 \\
Enterekok CFU/100 ml & 1 \\
Escherichia Coli (E.coli ) CFU/100 ml & 1 \\
Pseudomonas aeruginosa CFU/100 ml & 40 \\
Toplam Bakteri Sayısı (22 ${ }^{\circ} \mathrm{C}$ ) CFU/1 ml & $>200$ \\
Toplam Koliform CFU/100 ml & 107 \\
\hline
\end{tabular}

\section{Çalıșmada Kullanılan Hidrodinamik Kavitasyon Sistemi}

Arıtma çamurlarının hidrodinamik kavitasyon denemeleri orifis plakalı kavitasyon cihazı ile yürütülmüștür. Kullanılan sistem 20 It hacminde paslanmaz çelikten yapılmıș bir reaktör, 1,5 kw motor gücüne sahip dikey milli santrifüj pompa ve kavitasyonun gerçekleștiği orifis kısmından olușmaktadır (Șekil 1). Pompanın deșarj kısmına bağlı olan boru ana hat ve bypass hattı olmaküzere dallanmaktadır. Ana hat üzerine takılan farklı delik çaplarına sahip orifis plakaları farklı yoğunluklarda ve özelliklerde kavitasyon olușumunu mümkün kılmaktadır. Bir orifis plakası, hatta boru flanșları arasına yerleștirilerek akıș hızının artmasına ve basıncın azalmasına neden olur. Orifis plakalarının kullanıldığı hidrodinamik kavitasyon sistemlerinde delik çaplarının genellikle 5 mm'den küçük olduğu literatürden bilinmektedir (Chanda, 2012; Gogate ve Pandit, 2000). Çalıșma kapsamında denenecek orifis plakanın delik çapı literatürle uyumlu olarak $3 \mathrm{~mm}$ olarak seçilmiștir. Sistem 5 bar basıncında çalıșmıștır.

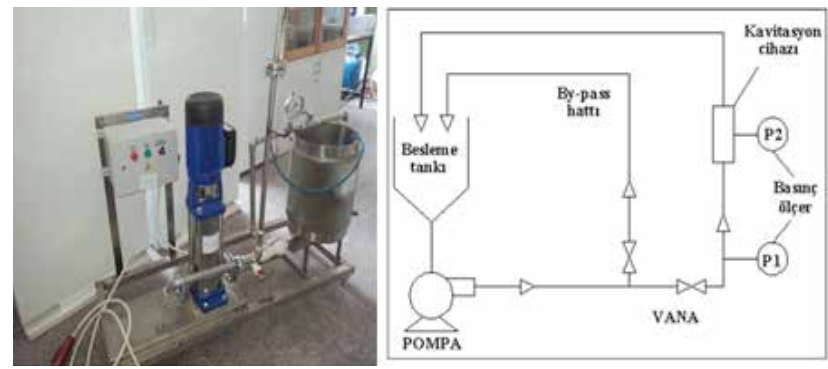

Șekil 1. Çalıșmada kullanılan hidrodinamik kavitasyon sistemi Figure 1. Hydrodynamic cavitation system used in operation

\section{Kavitasyon sayısının (Ks)hesabı}

Kavitasyon sayısı, Cv olarak bilinen boyutsuz bir sayıdır ve kavitasyon yoğunluğu ile debi șartlarını ilișkilendirmek için kullanılmaktadır. İdeal șartlarda kavitasyon, $\mathrm{C} v<1$ olduğunda olușmaktadır. Kavitasyon sayısı Eșitlik 1'de verilen formülle hesaplanmaktadır (Gogate ve Pandit, 2000).

$C_{V}=\left(P_{2}-P_{v}\right) /\left(0,5^{*} P^{*} V^{2}{ }_{\text {th }}\right) \quad($ Eș. 1$)$

Yukarıdaki denklemde $P_{2}$ tamamen geri kazanılan așağı akım basıncını, Pv sıvının buhar basıncını ve Vth daralma bölgesindeki sıvı hızını ifade etmektedir.

Ks hesabı için kavitasyon ișlemi bașlatılmadan önce kavitasyon hücresindeki çamur örneğinin 3 L'sinin boș bir kabı kaç saniyede doldurduğu tespit edilmiștir. Bulunan sonuç 17 saniyedir. Yapılan matematiksel hesaplar așağıda sıralanmıștır:

$-0,176 \mathrm{~L} / \mathrm{sn}=1,764 * 10^{-4} \mathrm{~m}^{3} / \mathrm{sn}=\mathrm{O}$ (Debi)

$-A=\frac{\pi}{4} d^{2}$ (orifisin yarıçapı $1,5 \mathrm{~mm}^{\prime} \mathrm{dir}$ ). $A=7,065^{*} 10^{-6}$ $\mathrm{m}^{2}$ (Alan)

$-V$ th $=Q / A \rightarrow\left(1,764 * 10-4 \mathrm{~m}^{3} / \mathrm{sn}\right) /\left(7,065^{*} 10^{-6}\right.$

$\left.\mathrm{m}^{2}\right)=24,98 \mathrm{~m} / \mathrm{sn}(\mathrm{HIz})$

-101325 (açık hava basıncı) - 3500 (suyun buhar

basıncı) $=97825$ bar

$-C_{v}=\left(P_{2}-P_{v}\right) /\left(0,5^{*} P^{*} V^{2}{ }_{\text {th }}\right)$

$-C_{V}=(101325-3500) /(0,5 * 1000 * 24,982)=0,31$

olarak hesaplanmaktadır.

\section{Kavitasyon Süresince İzlenen Mikrobiyolojik Parametreler}

Kavite edilen su numunesinden kavitasyonun 0., 30., 60., 90., 120. ve 150. dakikalarında örnekler alınmıș ve tüm örneklerde Toplam Canlı Sayısı, E.Coli, Toplam Koliform, Enterokok, Clostridium Perfingers, Pseudomonas aeruginosa analizleri yapıımıștır.

\section{Mikrobiyolojik Analizlerde Kullanılan Yöntemler}

Pseudomonas aeruginosa'nın tespiti ve sayımı Membran Filtrasyon yöntemi ile TS EN ISO 16266:2006standartınagöreyapılımıștır. Membran filtre sisteminden numune suyu süzülerek seçici besiyerine (CN Agar) yerleștirilmiș ve $(36 \pm 2)^{\circ} \mathrm{C}^{\prime} \mathrm{de}$ $48 \pm 4$ saat sonunda olușan koloniler sayılmıștır. Doğrulama için Asetamit testinin yapılması sonucu Pseudomonas aeruginosa tespiti yapılmıștır.

Toplam Koliform ve E.coli tespiti ve sayımı Membran Filtrasyon yöntemi ile TS EN ISO 93081 standartına göre yapıımıștır. Deney numunesi, bakterileri geçirmeyen bir membran filtreyle 
süzülmüș ve bu filtre kromojenik Koliform agar (CCA) üzerine yerleștirilmiștir. Bu membranlar $(36 \pm 2)^{\circ} \mathrm{C}$ de $(21 \pm 3)$ saat inkübe edilmiștir. B-D-galactosidase pozitif koloniler (pembeden kırmızıya) muhtemel Koliform olarak saylırlar. Aeromonas spp gibi oksidaz pozitif bakterilerin neden olduğu yalancı pozitif reaksiyonu ayırmak için, muhtemel koloniler negatif oksidaz (oksidaz testi) reaksiyonu ile doğrulanmıștır. ß-Dgalaktosidaz ve ß-D-glukuronidaz pozitif koloniler (besiyerinde menekșe morundan laciverte kadar olan koloniler) E. coli olarak sayılmıștır. Toplam Koliform sayımı ise E. coli sayısı ile oksidaz negatif olan Koliform bakterilerin toplamı sonucu elde edilmiștir.

Membran Filtrasyon yöntemiyle bağırsak Enterekoklarının tespiti ve sayım yöntemi TS EN ISO 7899-2 standartına göre yapılmıștır. Membran filtre sisteminden $10.45 \mu \mathrm{m}$ ve $47 \mathrm{~mm}$ çapında çizgili steril Membran Filtre Kağıdı) numune suyu süzülerek seçici besiyerine (Slanetz Bartley) yerleștirilmiș ve Petri plağı $(36+2)^{\circ} \mathrm{C}$ de $(44 \pm 4)$ saat inkübe edilmiștir. Tipik olarak koloninin ortasında veya etrafinda, kırmızı, mor veya pembe renk olușumu ile ortaya çıkan tüm koloniler dikkate alınarak safraeskulin-azid agarlı petri ile doğrulama testi yapılmıștır.

Dökme Plak Metoduyla Toplam Canlı tayini TS EN ISO 6222 -02/2002 standartına göre yapılmıștır. $1 \mathrm{ml}$ su örneği dökme plak metoduyla Yeast - Extract seçici besiyerine așılanarak, (22 \pm 1$)$ ${ }^{\circ} \mathrm{C}$ de $(68 \pm 4)$ saat sonunda olușan tüm kolonilerin sayılması sonucu olușan Toplam canlı (Aerobik bakteri, maya ve küf ) sayısı bulunmuștur.

Membran Filtrasyon Metodu ile Clostridium Perfringens (Sporlular dahil) Annex Council Directive 111/98/83/EC standartına göre yapılmıștır. Su numunesi, membran filtrasyon sisteminde $0,22 \mu \mathrm{m}$ filtreden süzülerek (m-CP) agara ekim yapılarak, $44 \pm 1^{\circ} \mathrm{C}^{\prime} \mathrm{de}$ anaerobik ortamda (Anaero jar) $21 \pm 3$ saatlik inkübasyona tabi tutulmuștur. İnkübasyon sonrası petri kabında olușan opak sarı koloniler 20-30 saniye süresince amonyum hidroksit $\left(\mathrm{NH}_{4} \mathrm{OH}\right)$ buharına tutulmuș ve kolonilerden pembe ya da kırmızıya dönenler C. perfringens olarak kabul edilmiștir.

\section{BULGULAR VE TARTIȘMA}

İçilebilir nitelikteki suların mikrobiyal kalitesi sağlık açısından büyük önem tașımaktadır.
Hastalık yapıcı mikroorganizmaların giderilmesi, dezenfeksiyon etkinliğinin değerlendirilmesi açısından ele alınmaktadır.

Suların bakteriyolojik kalitesi, indikatör mikroorganizmalarca belirlenmektedir. Bu amaçla sularda bașta koliform, fekal koliform ve E. coli olmak üzere genel canlı sayısı, Enterokok ve sülfit indirgeyen anaerob'lar aranmaktadır. Bu bakterilerin sudaki varlığı, direkt ya da dolaylı yolla bir fekal bulașmayla birlikte patojenlerin de bulunma olasıllığını ve hijyenik kalitenin yetersizliğini ifade etmektedir (Murcia vd., 2017).

Șekil 2'de seçilen mikroorganizmaların kavitasyon esnasında zamana bağlı olarak gösterdikleri değișim gösterilmektedir. Kavitasyon süresince tüm mikroorganizmaların azaldığı görülmüștür. Kavitasyonun ilk 60. dk'sında giderimin büyük ölçüde sağlandığı görülmüștür. 90. dk'nın sonunda ise tamamen giderim gerçekleșmiștir.

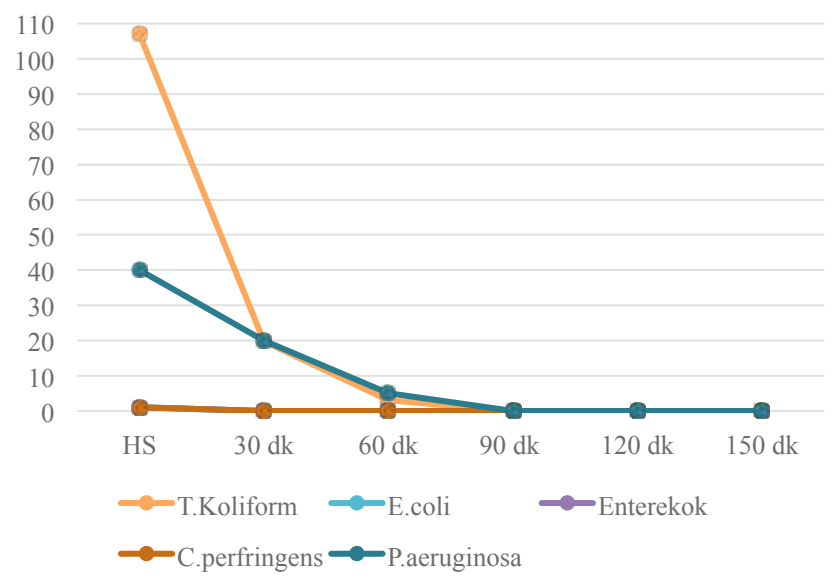

Șekil 2. Kavitasyon süresine bağlı olarak mikroorganizma sayılarının değișimi

Figure 2. Variation of microorganism levels during cavitation time

Enterobacteriaceae familyasında yer alan $E$. coli, insan ve sıcakkanlı hayvanların bağırsak florasında doğal olarak bulunur. Bazı türleri patojen özellik tașır. Patojen olan türler insanlarda gastroenterit ve çeșitli hastalıklara neden olur. E. coli enfeksiyonlarından korunmada hijyen kurallarının uygulanması oldukça önemlidir. Çalıșmada, E. coli ham suda (HS) bașlangıçta 1CFU/100 ml olarak tespit edilmiștir. Kavitasyonun ilk 30.dk'sında E. coli gideriminin tamamen sağlandığı görülmüștür. Mezule vd. (2009) tarafından yapılan laboratuvar ölçekli çalıșmada 
3. dk da \%75 giderim elde edilmiștir. Vitenko ve Gashchyn (2014) tarafından yapılan çalıșmada ise en yüksek dezenfeksiyon oranı $\sigma=0,5$ kavitasyon sayısında 14. dk da \%82 olarak bulunmuștur.

Kavitasyon sayısına göre çalıșma sonuçları değerlendirildiğinde $\sigma=0,31$ kavitasyon sayısında 30. dk sonunda \%100 giderim gerçekleștiği görülmüștür.

Balasundaram ve Harrison (2006) orifis plaka kullanarak intracellular proteinlerin salınmasını sağlayarak E. Coli yıkımını gerçekleștirmișlerdir.

Clostridium perfringens, Bacillaceae familyasına ait Gram pozitif, uçları yuvarlak çubuk șeklinde sporlu, kapsüllü, anaerobik, hareketsiz bir bakteridir. Clostridium perfringens su analizlerinde önemli bir rol oynar. Vejetatif hücrelerle kıyaslandığında ısıya dirençli spor formunda bulunabilmesi, bu organizmaların sulardan tespiti için bir avantaj olarak kullanılır. C.perfringens en önemli sülfit indirgeyen Clostridium cinsi bakteridir ve insan ve hayvan dıșkısında doğal olarak bulunur. Clostridial sporlar sularda koliform bakterilerden, E.coliden ve Enterokoklardan daha uzun yașar ve eski fekal kirliliğin göstergesi olarak kullanılır. Sporlar her zaman klorlamayla da inaktive olmaz. Yüzey suları gibi çevresel sularda, geniș bir dağılıma sahip olan Clostridium türlerinin pek çoğu bulunabilir. Clostridium türlerinin pek çoğu $44^{\circ} \mathrm{C}$ 'de üremezken C.perfringensürer. Bu nedenle $44^{\circ} \mathrm{C}^{\prime}$ de inkübasyon, bazı numunelerde C.perfringens'in izole edilmesi için seçiciliği artırabilir (Berberoğlu, 2012). Sekil 2 incelendiğinde ham suda bașlangıçta 1CFU/100 ml olan sayının ilk 30 dk'da giderildiği görülmektedir.

Pseudomonas aeruginosa sporsuz, polar flagellalı, hareketli, Gram negatif, genellikle kapsülsüz mikroorganizmadır. $P$. aeruginosa genellikle sistemik infeksiyonlara neden olmaktadır. Üriner sistem ile ilgili birçok hastalıktan sorumludur. Bu nedenle sularda bulunması istenemez. P. aeruginosa bașlangıçta 40 CFU/100 $\mathrm{ml}$ olarak tespit edilmiș olup, ilk $60 \mathrm{dk}$ sonunda $\%$ 87,5'lik bir giderim $(0,90$ log'luk) sağlandığı görülmüștür. $90 \mathrm{dk}$ sonunda ise $\% 100$ giderim elde edilmiștir.

Dindar ve Topaç (2018), yaptıkları çalıșmada atıksuyun hidrodinamik kavitasyon sonucunda P. aeruginosa için en belirgin azalmanın 90. dk sonunda \%79'luk bir giderim oranında gerçekleștiğini, kavitasyon sonunda (150.dk) ise yaklașık \%98'lik bir giderim sağlandığı bulmușlardır.
Bağırsak enterokokları Gram-pozitif, genelde zincir formlu, katalaz-negatif ve kokoid-yumurta șekli arasında olabilen ve $D$ antijenine sahip bakterilerdir. Enterokoklar insan ve hayvanların gastrointestinal sisteminde kommensal yașayan, firsatçı patojenlerdir ve idrar yolu enfeksiyonu, endokardit ve sepsise neden olan bakterilerdir (Poulsen vd., 2012; Shafi vd., 2017). Sularda enterokoklar ve stafilokoklar hem fekal hem de organik kontaminasyon indikatörü olarak kullanılmaktadır (Karafistan ve Çolakoğlu,2005). Ham suda 100 ml'de 1 CFU olarak tespit edilen enterokokun ilk $30 \mathrm{dk}$ sonunda giderimi sağlanmıștır.

Toplam koliform bakteri sayısı, su kalitesinin en güvenilir göstergesi olarak kullanılır. Koliform bakteriler insan ve hayvan bağırsağında bulunabileceği gibi çevresel ortamda da bulunabilir ve potansiyel fekal kirliliğin göstergesi olabilirler. Fekal koliformlar ve E.coli ise sadece insan ve hayvan bağırsağında bulunur ve sulardaki varlıkları için yapılan testler, insan ve hayvan orijinli dıșkı kirliliğin doğrulanması için gereklidir (Berberoğlu, 2012). Toplam kolifom sayısı değerlendirildiğinde ham suda 107,1 CFU/100 ml bulunduğu belirlenmiștir. \%82 oranında ciddi bir giderim ilk 30 dk da giderildiği görülmüștür. 60 dk sonunda ise \%97 oranında (1,54 log) giderim gerçekleștiği bulunmuștur.

Șekil 3'de hidrodinamik kavitasyon prosesi boyunca $22^{\circ} \mathrm{C}^{\prime}$ de toplam canlı sayısının değișimi gösterilmektedir. Toplam canlı sayısı, su analizlerinde hijyen indeksi olarak yaygın șekilde kullanılmaktadır. Bu bakterilerin yoğunluğu, suyun hijyenik kalitesi yanı sıra patojenlerin bulunma olasılığını da değerlendirmede yardımcı olmaktadır (Alemdar, 2009).

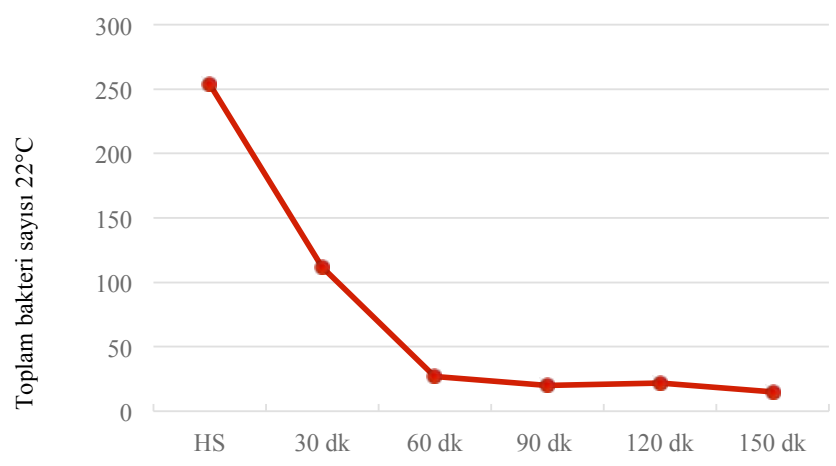

Șekil 3. Kavitasyon süresince toplam bakteri sayısının değișimi

Figure 3. Variation of total bacterial count during cavitation time 
Ham suda toplam canlı sayısı 254 CFU/ml olarak tespitedilmiș olup, kavitasyon süresince azaldığı tespit edilmiștir. İlk $60 \mathrm{dk}$ sonunda toplam canlı sayısında \%89 oranında $(0,90 \mathrm{log})$ ciddi bir azalma meydana geldiği görülmüstür. 90 dk dan sonra toplam canlı sayısında belirgin bir değișim olmadığı gözlenmiștir. Kavitasyonun sonunda ise \%94 oranında (1,23 log) toplam canlı sayısında azalma meydana geldiği tespit edilmiștir. Loraine vd. (2012) yaptığı çalıșmada, atıksuda 45 dakikalık kavitasyon sonrası tüm bakteri miktarında \%80'lik azalıș olduğunu gözlemlemiștir. Hidrodinamik kavitasyonun gram-negative E. coli, Klebsiella pneumoniae, Pseudomonassyringae and Pseudomonas aeruginosa and gram positive Bacillus subtilis türlerinin konsantrayonlarının azalmasında çok etkili olduğunu bulmușlardır.

\section{SONUÇLAR}

Hidrodinamik kavitasyon, bir akıs sisteminde akıș kısıtlaması ile meydana gelen hızlı basınç dalgalanmalarına ve önemli akıșkan kuvvetlerine neden olan bir sistemdir. Bu sayede, hidrodinamik kavitasyon mikrobik hücre hasarına yol açmaktadır. Dolayısıyla, suların dezenfeksiyonu için hidrodinamik kavitasyon etkili bir yöntem olarak kullanılabilmektedir. Bu çalıșma sonucunda 5 bar basıncında ve 0,31 kavitasyon sayısı ile çalıșan bir sistemde ilk 60 dk sonunda etkili bir mikrobiyal giderim sağlandığı görülmüștür. Hidrodinamik kavitasyonda, dezenfeksiyon için herhangi bir kimyasal madde kullanılmadan dezenfeksiyonun sağlanması ekonomik ve çevre dostu bir sistem olarak daha avantajlı bir yöntem olarak değerlendirilmektedir.

İçme ve kullanma sularında insan sağlığı açısından bulunması istenmeyen E.Coli, Toplam Koliform, Enterokok, Clostridium Perfingers, Pseudomonas aeruginosa gibi mikroorganizmaların giderilmesinde etkili olduğu yapılan çalıșma sonucunda ortaya konmuștur.

Son yıllarda su ve atıksu arıtımı konularında etkili ve ekonomik bir yöntem olarak ön plana çıkan hidrodinamik kavitasyon prosesinin, su dezenfeksiyon alanındaki kullanılabilme potansiyelini mikrobiyolojik düzeyde ortaya çıkarması açısından önem tașımaktadır.

\section{TEȘEKKÜR}

Bursa Büyükșehir Belediyesi, BUSKi Genel Müdürlüğü, Dobruca İçme Suyu Arıtma Șube Müdürlüğü'ne katkılarından dolayı teșekkür ederim.

\section{KAYNAKLAR}

Alemdar S, Kahraman T, Ağaoğlu S, Alișarlı M (2009) Bitlis İli İçme Sularının Bazı Mikrobiyolojik ve Fizikokimyasal Özellikleri, Ekoloji 19, 73, 29-38.

Arrojo S, Benito Y, Tarifa AM (2008) A Parametrical Study of Disinfection with Hydrodynamic Cavitation, Ultrasonics Sonochem., 15(5) 903-908.

Balasundaram B, Harrison STL (2006) Study of Physical and Biological Factors Involved in the Disruption of E. coli by Hydrodynamic Cavitation Biotechnol. Prog., 22, 907-913.

Berberoğlu U (2012) Su Mikrobiyolojisi ve Uygulamaları El Kitabı, Türkiye Halk Sağığı Kurumu, Ankara.

Chanda SK (2012) Disitegration of sludge using ozonehydrodynamıc cavitation, Master of Applied Science in the Faculty of Graduate Studies (Civil Engineering), The University of British Columbia, Vancouver.

Council Directive 98/83/EC on the Quality of Water Intended for Human Consumption: Calculation of Derived Activity Concentrations.

Dindar E, Topaç Șağban FO (2018) Uluslararası Su ve Cevre Kongresi, SUCEV2018 Bildiriler Kitabı, 1434-1442, 2224 Mart, Bursa.

Giese N, Darby J (2000) Sensitivity of Microorganisms to Different Wavelengths of UV Light: Implications on Modeling of Medium Pressure UV Systems, Water Res. 34 (16) 40074013.

Gogate PR, Pandit AB (2000) Engineering Design Methods For Cavitation Reactors II: Hydrodynamic Cavitation, AICHE Journal, 46 (8), 1641-1649

Haas CN, Heller B (1990) Kinetics of Inactivation of Giardia Lambia By Free Chlorine, Water Res. 27 (2) 233-238.

Jyoti KK, Pandit AB (2001) Water Disinfection by Acoustic and Hydrodynamic Cavitation, Biochem. Eng. J. 7, 201-212.

Karafistan A, C.olakoğlu FA (2005) Physical, Chemical and Microbiological Water Quality of the Manyas Lake, Turkey. Mitigation and Adaptation Strategies for Global Change. 10, 127- 143.

Labatiuk CW, Belosevic M, Gordon FR (1992) Factors Infuencing The Infectivity Of Giardia Muris Cysts Following Ozone İnactivation in Laboratory and Natural Waters, Water Res. 26 (6) 733- 743.

Li X, et al. (2016).Gas-liquid Mass Transfer Characteristics with Microbubble Aeration - I. Standard stirred tank. Chem Eng Technol., 39(5), 945-952.

Loraine G, Chahine G, Hsiao CT, Choi JK, Aley P (2012) Disinfection of Gram-Negative and Gram-Positive Bacteria

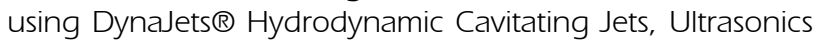
Sonochemistry, 19 (3), 710-717.

Mason TJ, Joyce E, Phull SS, Lorimer JP (2003) Potential Uses of Ultrasound in the Biological Decontamination of Water, Ultrason. Sonochem. 10, 319-323.

Mezule L, et al. (2009). A Simple Technique For Water Disinfection with Hydrodynamic Cavitation: Effect on Survival of Escherichia coli. Desalination; 248 (1-3), 152-9. 
Murcia JJ, Avila-Martinez EG, Rojas H, Navio JA, Hidalgo MC (2017) Study of the E.coli elimination from urban wastewater over photocatalysts based on metallized $\mathrm{TiO} 2$. Applied Catalysis B: Environmental. 200, 469-476.

Poulsen LL, Bisgaard $M$, Son NT, Trung NV, An HM, Dalsgaard A (2012) Enterococcus faecalis Clones in Poultry and in Humans with Urinary Tract Infections, Vietnam. Emerging Infectious Diseases Journal. 18(7), 1096-1 100.

Save SS, Pandit AB, Joshi JB (1994) Use of Hydrodynamic Cavitation For Large Scale Microbial Cell Disruption, Chem. Eng. J. 55, B67.

Shafi S, Kamili AN, Shah MA, Parray JA, Bandh SA (2017). Aquatic Bacterial Diversity: Magnitude, Dynamics, and Controlling, Microbial Pathogenesis, 104, 39-47.

Szulży-Cieplak J, Ozonek J (2013) The Study of the Impact of Select Parameters of Hydrodynamic Cavitation System on Anthracene an Penanthrene Degrardation Rate in Cavitated Liquid Environment) Annual Set the Environment Prorotection 15, 996-1010.
TSENISO 16266 Water quality-Detection and enumeration of Pseudomonas aeruginosa - Method by membrane filtration.

TS EN ISO 6222 Water quality- Enumeration of culturable microorganisms- Colony county by inoculation in a nutient agar culture medium.

TS EN ISO 7899-2 Water quality - Detection and enumeration of intestinal Enterococci - Part 2: Membrane filtration method.

TS EN ISO 9308-1 Water quality- Detection and enumeration of Escherichia coli and coliform bacteria Part-1 Membran filtration method.

Vitenko T, Gashchyn O (2014) Mechanism and Kinetic Regularities of Inactivating Effects of Cavitation on Microorganisms, Chemistry \& Chemical Technology. Vol. 8, № $4,431-440$. 